\title{
Molecular characterization of phenanthrene-degrading methanogenic communities in leachate-contaminated aquifer sediment
}

\author{
S. Y. Zhang $\cdot$ Q. F. Wang $\cdot$ S. G. Xie
}

Received: 21 April 2011/Revised: 4 October 2011/Accepted: 12 December 2011/Published online: 18 July 2012

(c) CEERS, IAU 2012

\begin{abstract}
The existence of polycyclic aromatic hydrocarbons in the various environments has aroused great environmental concerns due to their potential hazards to human health. The presence of polycyclic aromatic hydrocarbons in aquifer is particularly sensitive where groundwater is used as a source of potable water. Anaerobic biodegradation of polycyclic aromatic hydrocarbons is an attractive option for remediation of contaminated aquifer sediment. Bacterial and archaeal community structures of phenanthrene-degrading aquifer sediment under methanogenic condition were investigated using clone library analysis in combination with microcosm study. The bacterial members were all affiliated with $\gamma$-Proteobacteria. Phylum Euryarchaeota was the predominant archaeal group, represented by genera Methanosarcina, Methanobacterium and Thermogymnomonas. Both bacteria (genera Citrobacter and Pseudomonas) and archaea (genus Methanosarcina) might have links to phenanthrene degradation process. This work might provide some new insights into developing strategies for the isolation of the putative polycyclic aromatic hydrocarbons degraders under methanogenic condition and bioremediating polycyclic aromatic hydrocarbons in leachatecontaminated aquifer sediment.
\end{abstract}

Keywords Anaerobic biodegradation - Archaea . Bioremediation - Groundwater - Microbial structure . Polycyclic aromatic hydrocarbons

S. Y. Zhang · Q. F. Wang · S. G. Xie (ه)

College of Environmental Sciences and Engineering,

Peking University, Beijing 100871, China

e-mail: xiesg@pku.edu.cn

\section{Introduction}

Polycyclic aromatic hydrocarbons (PAHs) are mainly produced from incomplete combustion of organic materials and fossil fuels in various industrial activities, such as coking plants, thermo-power plants and refinery plants. The existence of PAHs in the various environments has aroused great environmental concerns. The United States Environmental Protection Agency has listed 16 typical PAHs as the priority pollutants. The presence of PAHs in aquifer is particularly sensitive where groundwater is used as a source of potable water. The major process for successful removal of PAHs from contaminated sites is biological degradation (Yuan et al. 2001; Yousefi Kebria et al. 2009; Abdulsalam et al. 2011). To date, aerobic PAH-degraders and biodegradation pathways have been well documented (Bamforth and Singleton 2005; Haritash and Kaushik 2009). However, due to both the low amount of dissolved oxygen and the slow diffusion of oxygen into subsurface, those degraders can rapidly deplete oxygen, which suggests that anaerobic degradation might be more attractive in the subsurface environments (Chang et al. 2005a). Numerous studies have investigated PAH biodegradation under different redox conditions, mostly with nitrate or sulfate as terminal electron acceptors (Meckenstock et al. 2004; Chang et al. 2005b). Methanogenic condition can be formed due to the depletion of electron acceptors such as oxygen, nitrate, sulfate and iron (Chang et al. 2006). However, little information is available for PAH biodegradation under methanogenic conditions (Chang et al. 2005b, 2006). Methanogenic condition can be formed due to the depletion of electron acceptors such as oxygen, nitrate, sulfate and iron (Chang et al. 2006). However, little information is available for PAH biodegradation under methanogenic conditions (Chang et al. 2005b, 2006). 
Molecular techniques have been widely employed to identify members of microbial communities without isolating an individual species in pure cultures.

These tools are especially useful when pure cultures are not easily obtained, which is often the case for anaerobic cultures (Chang et al. 2005a). Leachate from municipal solid waste (MSW) composting site may lead to serious PAH contamination in aquifers (Jiries et al. 2005). Numerous studies have investigated the structures of bacterial communities in leachate-contaminated aquifers (Gros et al. 2003; Tian et al. 2005; Yu et al. 2010). However, all these previous works have not investigated the links of the microbial communities to PAH biodegradation. Few previous investigations on the $\mathrm{PAH}$-degrading communities under methanogenic conditions focused on harbor sediment (Chang et al. 2005b, 2006). Therefore, the information on microbial community structure in PAH-degrading aquifer sediment is still lacking. In this study, the leachate-contaminated aquifer sediment was incubated with phenanthrene in minimal medium under methanogenic condition. The aim of this study was to investigate the bacterial and archaeal community structures of phenanthrene-degrading microcosms under methanogenic condition. To the authors' knowledge, this was the first report characterizing microbial communities in aquifer sediment degrading PAHs under methanogenic condition. Therefore, identifying the microbial communities in association with phenanthrene degradation will provide more insights on how to bioremediate PAHs in aquifer sediment. Raw aquifer sediments were collected in the year in the spring of 2010 in Changzhou, China, and the investigation was carried out between May 2010 and March 2011 at the College of Environmental Sciences and Engineering, Peking University, China.

\section{Materials and methods}

Microcosm experimental setup and chemical analysis

Aquifer sediment ( $5 \mathrm{~m}$ below the ground surface) was studied in the vicinity of an MSW composting site with a nearly 2-year history in Changzhou, a southeast city in China. Preliminary research of this study indicated that the sediment contained $300-400 \mu \mathrm{g} / \mathrm{kg}$ total PAHs including $20-30 \mu \mathrm{g} / \mathrm{kg}$ phenanthrene. The collected sediment was air dried, homogenized and sieved through a $0.18 \mathrm{~mm}$ screen, and stored at $4{ }^{\circ} \mathrm{C}$ until use; $200 \mu \mathrm{g}$ of phenanthrene (98\%, Sinopharm Chemical Reagent Beijing Co., Ltd) dissolved in methanol was separately added to each empty microcosm chamber $(150 \mathrm{ml}$ serum bottle). After the methanol evaporated, $3 \mathrm{~g}$ of dry sediment was added to each microcosm along with $20 \mathrm{ml}$ of mineral salt medium.
The mineral salt medium was prepared as in the literature (Yang and McCarty 1998) with minor revision. The mineral salt medium contained the following constituents per liter: $0.5 \mathrm{~g} \mathrm{~K}_{2} \mathrm{HPO}_{4}, 1.5 \mathrm{~g} \mathrm{Na}_{2} \mathrm{CO}_{3}, 20 \mathrm{ml}$ minerals solution $\left(40 \mathrm{~g} \mathrm{NaCl}, 50 \mathrm{~g} \mathrm{NH}_{4} \mathrm{Cl}, 5 \mathrm{~g} \mathrm{KCl}, 5 \mathrm{~g} \mathrm{KH}_{2} \mathrm{PO} 4,5 \mathrm{~g}\right.$ $\mathrm{MgCl}_{2} \cdot 6 \mathrm{H}_{2} \mathrm{O}$ and $2 \mathrm{~g} \mathrm{CaCl}_{2} \cdot 2 \mathrm{H}_{2} \mathrm{O}$ ) and $5 \mathrm{ml}$ trace metal solution $\left(1 \mathrm{~g} \mathrm{FeCl}_{2} \cdot 4 \mathrm{H}_{2} \mathrm{O}, 1 \mathrm{~g} \mathrm{MnCl}_{2} \cdot 4 \mathrm{H}_{2} \mathrm{O}, 0.2 \mathrm{~g} \mathrm{CoCl}_{2}\right.$. $6 \mathrm{H}_{2} \mathrm{O}, 0.12 \mathrm{~g} \mathrm{H}_{3} \mathrm{BO}_{3}, 0.02 \mathrm{~g} \mathrm{ZnCl}_{2}, 0.02 \mathrm{~g} \mathrm{CuCl}_{2} \cdot 2 \mathrm{H}_{2} \mathrm{O}$, $0.02 \mathrm{~g} \mathrm{NiCl}_{2} \cdot 6 \mathrm{H}_{2} \mathrm{O}, 0.02 \mathrm{~g} \mathrm{Na}_{2} \mathrm{MoO}_{4} \cdot 2 \mathrm{H}_{2} \mathrm{O}, 0.02 \mathrm{~g} \mathrm{Na}_{2} \mathrm{SeO}_{4}$, $0.02 \mathrm{~g} \mathrm{Na}_{2} \mathrm{WO}_{4} \cdot 2 \mathrm{H}_{2} \mathrm{O}$ and $\left.0.04 \mathrm{~g} \mathrm{Al}_{2}\left(\mathrm{SO}_{4}\right)_{3} \cdot 18 \mathrm{H}_{2} \mathrm{O}\right)$. No supplementary electron acceptors were added to the culture in this study. The non-oxygen microcosms were constructed, as previously described ( $\mathrm{Li}$ et al. 2010). The sterile controls were obtained by autoclaving at $120{ }^{\circ} \mathrm{C}$ repeatedly $(1 \mathrm{~h}$, three times). Microcosms were incubated on a horizontal shaker $(\sim 100 \mathrm{rpm})$ at $25^{\circ} \mathrm{C}$ for 120 days.

Gas headspace samples were taken every 30 days and analyzed for methane using a gas chromatograph with a thermal conductivity detector (TCD). The operational temperature of the column was $40{ }^{\circ} \mathrm{C}$, and the carrier gas $\left(\mathrm{N}_{2}\right)$ was at a flow rate of $30 \mathrm{ml} \mathrm{min}{ }^{-1}$ (He et al. 2008). Three replicates of samples were sacrificed every 30 days for phenanthrene analysis and sediment DNA extraction. The phenanthrene in solid phase was extracted and determined according to the standard methods (Zhang et al. 2011).

\section{Cloning and sequencing}

DNA was extracted from microcosm samples using the UltraClean DNA extraction kit (Mobio Laboratories). In this study, only sediment DNA from microcosm on day 120 was used for further molecular analysis. Bacterial 16S rRNA genes were amplified using bacterial primers $27 \mathrm{~F}$ ( $5^{\prime}$-GA GTTTGATCMT GGCTCAG-3') and 1492R (5'-GGTTA CCTTGTTACGACTT-3') (Zhang et al. 2011). Archaeal 16S rRNA genes were amplified with specific archaeal primers A109F (ACKGCTCAGTAACACGT) and A934R (GTGCTCCCCCGCCAATTCCT) (Großkopf et al. 1998). PCR conditions were as follows: $94{ }^{\circ} \mathrm{C}(5 \mathrm{~min}) ; 94{ }^{\circ} \mathrm{C}$ $(30 \mathrm{~s}) ; 55{ }^{\circ} \mathrm{C}(30 \mathrm{~s}) ; 72{ }^{\circ} \mathrm{C}(1.5 \mathrm{~min})(30$ cycles $) ; 72{ }^{\circ} \mathrm{C}$ (5 min) (Zhang et al. 2011). The PCR products were purified with QIA quick PCR purification kit (Qiagen Inc., German) and cloned into pMD19-T vector (Takara Corp, Japan). The white colonies were verified by PCR with primers M13 F (5'-TGTAAAACGACGGCCAGT-3') and M13 R (5'-AA CAGCTATGACCATG- $3^{\prime}$ ). Clones containing an insert of the correct size were sequenced at SinoGenoMax Co., Ltd. (Beijing).

Sequences were checked for chimeras with CHECK CHIMERA software of Ribosomal Database Project (RDP) II (Maidak et al. 2001). Sequences that were over $97 \%$ similar were grouped as an operational taxonomic unit 
(OTU) by manual comparison. The representative GenBank sequences of the selected clones in each OTU were extracted and included in further phylogenetic analyses. Phylogenetic trees were constructed by neighbor-joining analysis using MEGA version 4.0 software with 1,000 bootstrap replicates (Tamura et al. 2007). Bootstrap values $<50$ are not shown. The RDP II analysis tool "classifier" was utilized to identify taxonomic identity (Wang et al. 2007). The partial 16S rRNA gene sequences obtained in this study were submitted to GenBank under accession numbers HQ438887 to HQ438945 (bacterial clone library), and HQ438831 to HQ438886 (archaeal clone library).

\section{Results and discussion}

Phylogenetic analysis of bacterial community

Methane production in microcosms was observed during the whole biodegradation experiment, while the amount was negligible in the sterile controls, indicating the occurrence of methanogenesis in microcosms (data not shown). On day 120 , a significant decline of phenanthrene concentration (84-87\% reduction) in microcosms was observed, but the decline was limited in the autoclaved controls (5-7\% decrease), confirming the occurrence of biodegradation in microcosms. Chang et al. (2005b) revealed that 150 days of incubation was necessary for the disappearance of phenanthrene in methanogenic culture. Therefore, biodegradation of phenanthrene under methanogenic condition was a slow process.

Some profiling techniques such as community-level physiological profiling, restriction fragment length polymorphism and phospholipid fatty acid profiling have been applied to investigate the composition of bacterial community in leachate-contaminated aquifers (Gros et al. 2003; $\mathrm{Yu}$ et al. 2010). However, these techniques could not provide a direct phylogenetic identification of each profile in the pattern. Also, all these previous works have not investigated the microbial communities in association with PAH biodegradation. Phylogenetic studies of contaminated sites are useful for speculating which species are possibly involved in degradation activity and for further developing strategies for isolating the putative degraders (Chang et al. 2005b).

In order to investigate the bacterial community in sediment degrading phenanthrene, a bacterial 16S rRNA gene library was created with universal primers from 59 randomly chosen clones (Table 1). The bacterial library was divided into nine bacterial OTUs (BOTUs). The largest two BOTUs were BOTU7 (25 clones) and BOTU1 (18 clones), contributing to nearly $73 \%$ of the total sequences in
Table 1 Distribution of bacterial 16S rRNA gene clones (beginning with 'FCE') in the bacterial library

\begin{tabular}{|c|c|c|c|}
\hline $\begin{array}{l}\text { BOTU } \\
\text { no. }\end{array}$ & Clones & $\begin{array}{l}\text { Clone } \\
\text { numbers }\end{array}$ & $\begin{array}{l}\text { Putative } \\
\text { phylogenetic } \\
\text { affiliation (family, } \\
\text { genus) }\end{array}$ \\
\hline 1 & $\begin{array}{l}\text { FCE3, FCE6, FCE8, } \\
\text { FCE19, FCE20, } \\
\text { FCE21, FCE23, } \\
\text { FCE27, FCE28, } \\
\text { FCE29, FCE32, } \\
\text { FCE42, FCE48, } \\
\text { FCE50, FCE52, } \\
\text { FCE55, FCE59, } \\
\text { FCE60 }\end{array}$ & 18 & $\begin{array}{l}\text { Enterobacteriaceae, } \\
\text { Citrobacter }\end{array}$ \\
\hline 2 & FCE5, FCE16, FCE58 & 3 & Enterobacteriaceae \\
\hline 3 & FCE7, FCE40 & 2 & Enterobacteriaceae \\
\hline 4 & FCE34 & 1 & Enterobacteriaceae \\
\hline 5 & FCE38 & 1 & Enterobacteriaceae \\
\hline 6 & $\begin{array}{l}\text { FCE2, FCE4, FCE11, } \\
\text { FCE14, FCE49, } \\
\text { FCE56 }\end{array}$ & 6 & $\begin{array}{l}\text { Pseudomonadaceae, } \\
\text { Pseudomonas }\end{array}$ \\
\hline 7 & $\begin{array}{l}\text { FCE1, FCE9, FCE10, } \\
\text { FCE12, FCE13, } \\
\text { FCE17, FCE18, } \\
\text { FCE24, FCE25, } \\
\text { FCE26, FCE30, } \\
\text { FCE31, FCE33, } \\
\text { FCE35, FCE37, } \\
\text { FCE39, FCE41, } \\
\text { FCE43, FCE44, } \\
\text { FCE45, FCE46, } \\
\text { FCE47, FCE51, } \\
\text { FCE53, FCE57 }\end{array}$ & 25 & Pseudomonadaceae \\
\hline 8 & FCE15, FCE22 & 2 & Pseudomonadaceae \\
\hline 9 & FCE36 & 1 & \\
\hline
\end{tabular}

BOTU bacterial operational taxonomic unit

bacterial library, followed by BOTU6 (6 clones), BOTU2 ( 3 clones), BOTU3 ( 2 clones), BOTU8 ( 2 clones), BOTU4 (1 clone), BOTU5 (1 clone) and BOTU9 (1 clone).

The taxonomic identities of sequences in each BOTU were identified using the RDP II analysis tool "classifier" (Wang et al. 2007). All the bacterial clone sequences obtained in this study were affiliated with class $\gamma$-Proteobacteria. The dominance of class $\gamma$-Proteobacteria was also observed in leachate-polluted groundwater (Tian et al. 2005). Several previous reports have characterized the microbial communities in PAH-contaminated sites or degrading PAHs in aerobic conditions. For example, $\alpha-, \beta$ and $\gamma$-Proteobacteria predominated in a PAH-degrading soil/water system (Chang et al. 2007). $\beta$ - and $\gamma$-Proteobacteria were the major bacterial groups in an aged PAHcontaminated soil (Cébron et al. 2009). However, very little phylogenetic information is available for PAHdegrading microbial communities in anaerobic conditions. 


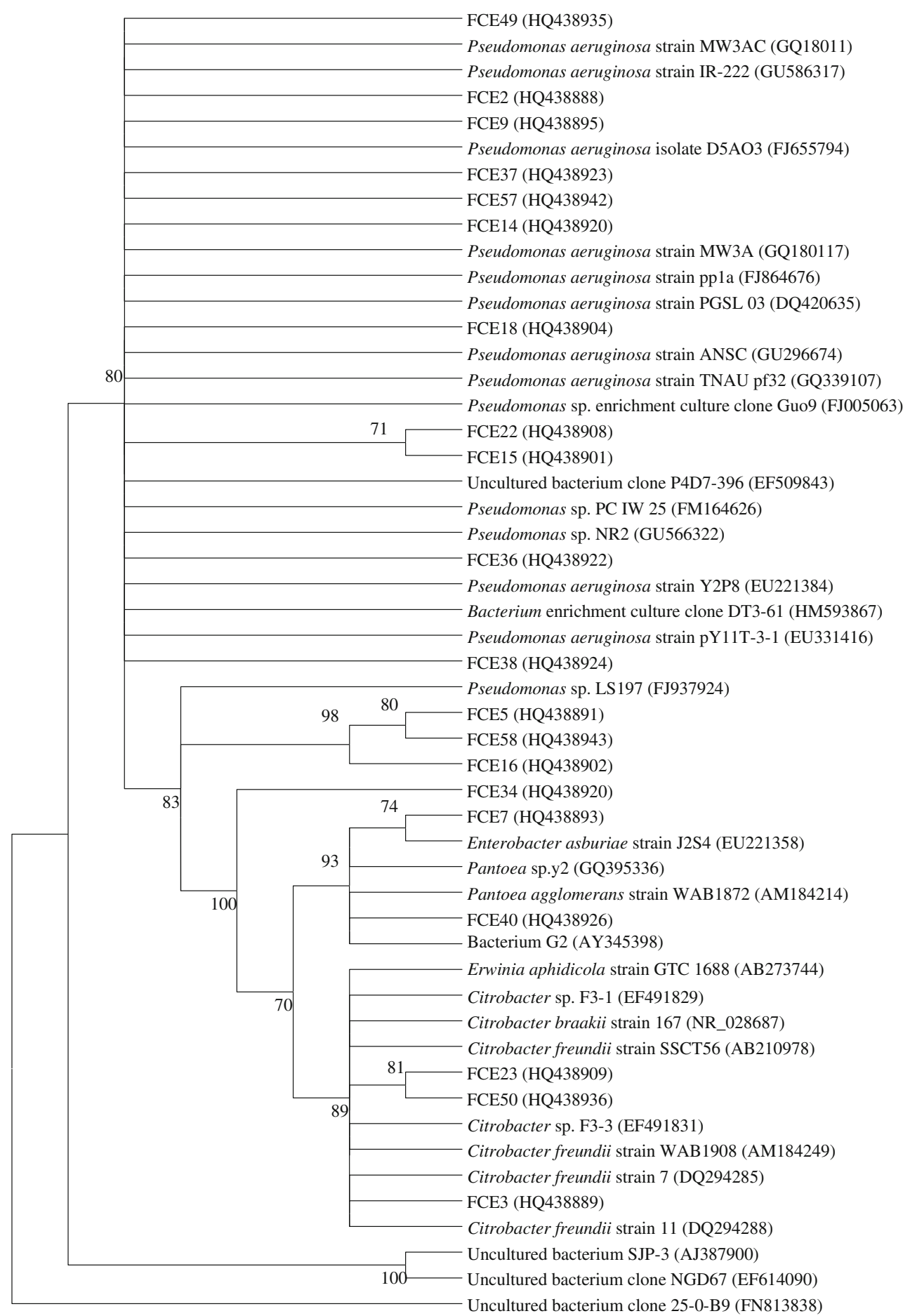

Fig. 1 Phylogenetic trees of representative bacterial 16S rRNA gene sequences in each bacterial OTU (beginning with 'FCE') and reference sequences from GenBank. Data in parentheses are GenBank accession numbers

$\delta$-Proteobacteria was the major bacterial phylum group in naphthalene-degrading methanogenic cultures initiated with Baltimore Harbor sediments, but phylum Firmicutes predominated in phenanthrene-degrading methanogenic cultures (Chang et al. 2005b). In this study, interestingly, all the bacterial clone sequences, obtained from aquifer sediment-degrading phenanthrene under methanogenic condition, were affiliated with $\gamma$-Proteobacteria.

All the members in BOTU1, BOTU2, BOTU3, BOTU4 and BOTU5 were affiliated with class $\gamma$-Proteobacteria, order Enterobacteriales, family Enterobacteriaceae. The members in these five OTUs accounted for nearly $42 \%$ of 
the total sequences in the bacterial library. However, all the members in BOTU6, BOTU7 and BOTU8 were affiliated with class $\gamma$-Proteobacteria, order Pseudomonadales, family Pseudomonadaceae. The members in these three OTUs accounted for nearly $56 \%$ of the total bacterial sequences. Moreover, the members in BOTU1 and BOTU6 could be further classified into the genera Citrobacter and Pseudomonas, respectively. However, BOTU9 (FCE36) belonged to unclassified $\gamma$-Proteobacteria.

Phylogenetic trees of representative bacterial 16S rRNA gene sequences in each BOTU were constructed (Fig. 1). In BOTU1, FCE3 was related with $95 \%$ identity to a Citrobacter freundii isolate (FJ768455.1). However, FCE23 had $97 \%$ similarity to a Citrobacter sp. isolate (DQ192061.1), obtained from asphalt seeps. FCE50 had $97 \%$ similarity to a Citrobacter freundii isolate (DQ294285.1). Several Citrobacter species have been linked to decolorization and degradation of triphenylmethane and azo dyes under anaerobic conditions (An et al. 2002; Wang et al. 2009), and biodegradation of $m$-cresol (Ren et al. 2009) and simple aromatic compounds (Ammar et al. 2005). A facultative anaerobic strain Citrobacter freundii was involved in anaerobic degradation of biphenyl (Grishchenkov et al. 2002). Narde et al. (2004) reported that a Citrobacter freundii strain could oxidize different substituted chlorophenol molecules. Savelieva et al. (2004) also reported the utilization of aminoaromatic acids by a methanogenic enrichment culture and by a Citrobacter freundii strain. More recently, Singh and Lin (2008) isolated a diesel oil-degrading Citrobacter freundii strain from hydrocarbon-contaminated soil. Therefore, the members in BOTU1 belonging to the genus Citrobacter might also have the link with phenanthrene biodegradation under methanogenic condition.

The closest matches for FCE5 and FCE16 in BOTU2 were uncultured clone sequences EF179822.1, EF179816.1 and EF614090.1 (with 93 or $94 \%$ identity), respectively. FCE58 was closely related with $96 \%$ identity to an uncultured bacterium (EF614090.1) obtained from a paddy soil. However, FCE5 and FCE16, FCE58 were related distantly from any known isolates, indicating that they represented novel taxa.

Both FCE7 and FCE40 in BOTU3 were closely related with $96 \%$ identity to an uncultured clone (AY376700.1). The closest match (95\% identity) for clone FCE34 in BOTU4 was an Erwinia aphidicola strain (AB273744.1). The clone FCE38 in BOTU5 was related distantly from any known isolates, and it had only $94 \%$ identity to an uncultured clone (GQ417710.1) obtained from a biological degreasing systems.

The representative clones in BOTU6 (FCE2, FCE14, FCE49) and BOTU7 (FCE9, FCE37, FCE57) were closely related with 96-97\% identity to many strains of Pseudomonas aeruginos and Pseudomonas sp. (GU296674.1, EU849119.1, EF433556.1, EU391389.1, AY548952.1 and
FM164626.1). The Pseudomonas aeruginosa strains (EU849119.1) could degrade naphthalene. Pseudomonas aeruginosa was one of the commonly studied PAH-degrading bacteria (Haritash and Kaushik 2009). The two clones in BOTU8 (FCE15 and FCE22) were with 94-95\% identity related to a Pseudomonas sp. isolate (FM164626.1). Species of genus Pseudomonas could biodegrade a wide variety of PAHs (Chang et al. 2007). The Pseudomonas accounted for $86.9 \%$ of the hydrocarbon-degrading microorganisms in gasoline-contaminated aquifers (Ridgeway et al. 1990). Pure cultures of several anaerobic nitrate-reducing and sulfatereducing bacteria, capable of degrading PAHs, have been identified in the previous works. Most of them were from the genus Pseudomonas (Haritash and Kaushik 2009). Therefore, the members in BOTU6, BOTU7, and BOTU8, belonging to the class Pseudomonadaceae, might also have the link with phenanthrene biodegradation.

Phylogenetic analysis of the archaeal community

To investigate the archaeal community in sediment degrading phenanthrene, an archaeal 16S rRNA gene clone

Table 2 Distribution of archaeal 16S rRNA gene clones (beginning with 'FCA') in the archaeal library

\begin{tabular}{|c|c|c|c|}
\hline $\begin{array}{l}\text { AOTU } \\
\text { no. }\end{array}$ & Clones & $\begin{array}{l}\text { Clone } \\
\text { numbers }\end{array}$ & $\begin{array}{l}\text { Putative } \\
\text { phylogenetic } \\
\text { affiliation (genus) }\end{array}$ \\
\hline 1 & $\begin{array}{l}\text { FCA1, FCA3, FCA9, } \\
\text { FCA11, FCA30, } \\
\text { FCA32, FCA34, } \\
\text { FCA41, FCA46, } \\
\text { FCA47, FCA51, } \\
\text { FCA54, FCA55, } \\
\text { FCA59, FCA61 }\end{array}$ & 15 & Methanosarcina \\
\hline 2 & $\begin{array}{l}\text { FCA2, FCA4, FCA5, } \\
\text { FCA6, FCA8, FCA10, } \\
\text { FCA13, FCA14, } \\
\text { FCA23, FCA25, } \\
\text { FCA28, FCA31, } \\
\text { FCA33, FCA35, } \\
\text { FCA36, FCA37, } \\
\text { FCA39, FCA42, } \\
\text { FCA43, FCA44, } \\
\text { FCA45, FCA48, } \\
\text { FCA49, FCA56, } \\
\text { FCA57, FCA62, } \\
\text { FCA63, FCA64 }\end{array}$ & 28 & Methanobacterium \\
\hline 3 & $\begin{array}{l}\text { FCA15, FCA19, FCA20, } \\
\text { FCA22, FCA26, } \\
\text { FCA29, FCA38, } \\
\text { FCA40, FCA50, } \\
\text { FCA52, FCA53, } \\
\text { FCA58 }\end{array}$ & 12 & Thermogymnomonas \\
\hline 4 & FCA7 & 1 & \\
\hline
\end{tabular}

AOTU archaeal operational taxonomic unit 
library was constructed with 56 clones (Table 2). The archaeal sequences were grouped into four archaeal OTUs (AOTUs). AOTU2 was the largest AOTU (28 clones), contributing to $50 \%$ of the total sequences in the archaeal library. AOTU1 and AOTU3 were grouped by 15 and 12 clones, respectively. However, only one clone was in AOTU4. All the clones in AOTU1, AOTU2 and AOTU3 were affiliated with archaeal phylum Euryarchaeota. However, the AOTU4 (FCA7) belonged to unclassified Archaea.

The 15 clones in AOTU1 could be furthered classified into class Methanomicrobia, order Methanosarcinales, family Methanosarcinaceae and genus Methanosarcina. The 30 clones in AOTU2 belonged to class Methanobacteria, order Methanobacteriales, family Methanobacteriaceae and genus Methanobacterium. Moreover, all the clones in AOTU3 fell within class Thermoplasmata, order Thermoplasmatales, family Thermoplasmatales_incertae_sedis and genus Thermogymnomonas.
Class Methanomicrobia was reported as the predominant archaea in phenanthrene-degrading methanogenic cultures initiated with harbor sediments (Chang et al. 2005b). Class Methanomicrobia was also the major phylogenetic archaeal group in the anoxic PAH-contaminated bay sediment (Kim et al. 2008). Moreover, members of class Methanomicrobia could be the important archaeal populations in landfill leachate (Huang et al. 2002) and in a landfill site (Mori et al. 2003).

Complete anaerobic degradation of complex hydrocarbons to carbon dioxide and methane generally requires at least several metabolic groups, including hydrolytic fermentative bacteria, syntrophic acetogenic bacteria and acetate- and hydrogen-utilizing methanogens (Ficker et al. 1999; Chang et al. 2005a). Chang et al. (2006) reported the involvement of methanogenesis in anaerobic PAH biodegradation. Kim et al. (2008) also suggested that methanogenesis-bearing archaeal populations were likely involved in PAH degradation process.

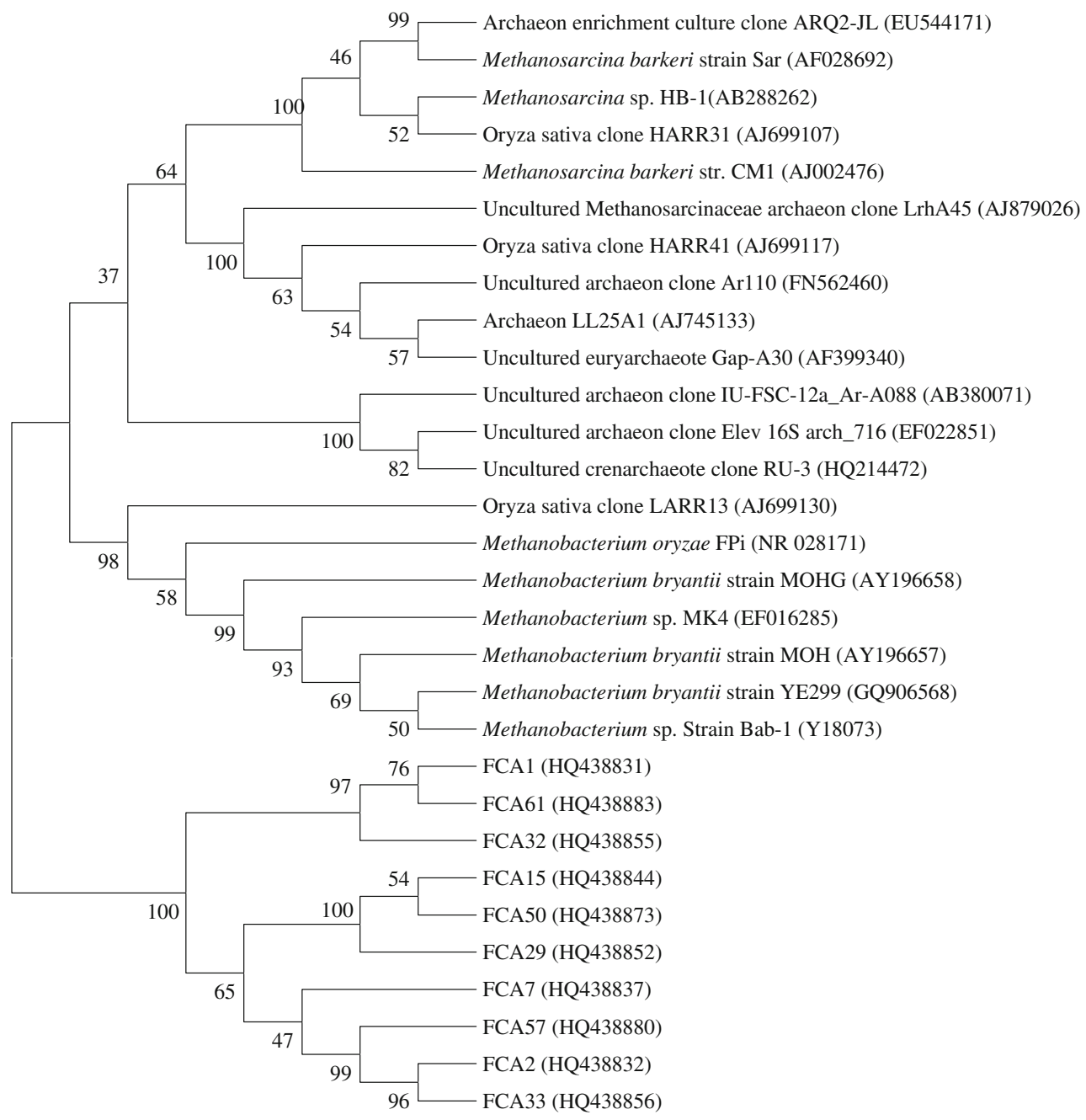

Fig. 2 Phylogenetic trees of representative archaeal 16S rRNA gene sequences in each archaeal OTU (beginning with 'FCA') and reference sequences from GenBank. Data in parentheses are GenBank accession numbers 
For this present study, phylogenetic trees of representative archaeal 16S rRNA gene sequences in each AOTU were also constructed (Fig. 2). In AOTU1, all the representative clones (FCA1, FCA32 and FCA61) were closely with $99 \%$ identity related to uncultured clones GQ458181.1, FM957960.1 and AJ831161.1, respectively. Moreover, clones FCA32 and FCA61 had $99 \%$ identity to two isolated Methanosarcina species (AB288262.3 and U89773.1), respectively. The aceticlastic methanogen, genus Methanosarcina, was also a major archaeal group in anoxic coastal marine sediments amended with petroleum compounds (Gilles et al. 2010). Chen et al. (2003a, b) reported that members of the genus Methanosarcina were the dominant archaeal population in the young-age MSW landfill soils and domestic solid waste landfill soils. Genus Methanosarcina has previously been linked to PAH biodegradation (Kim et al. 2008). Therefore, in this study, the abundance of Methanosarcina in archaeal community might also have links with PAH degradation.

The hydrogenotrophic methanogen, genus Methanobacterium, was the largest archaeal group in this study. Clones FCA2, FCA33 and FCA57 in AOTU2 were closely related with 99-100 \% identity to three isolated Methanobacterium strains (AY196658.1, EF016285.2 and AY196657.1). Methanobacterium members could be the major archaeal population in an upflow anaerobic sludge blanket (UASB) reactor (Sponza and Cigal 2008). The genus Methanobacterium was also present in domestic solid waste landfill soils (Chen et al. 2003b). However, in this study, the predominance of genus Methanobacterium in the archaeal community illustrated no direct relationship with PAH biodegradation.

AOTU3 fell within the genus Thermogymnomonas, which was also a major archaeal group in this study. The closest match (with $99 \%$ identity) for clones FCA15, FCA29 and FCA50 in AOTU3 was FN562465.1 or FN562460.1. Interestingly, in this study, its abundance in the archaeal community was observed in contaminated aquifer sediment in association with phenanthrene degradation. However, to the authors' knowledge, no information is available for its roles in reduction of any chemical compounds. The clone FCA7 in AOTU4 was distantly related from any known isolates, and its closest uncultured match (with $99 \%$ similarity) was sequence AB380071.1.

\section{Conclusion}

Bacterial and archaeal community structures of phenanthrene-degrading culture initiated with leachate-contaminated aquifer sediment under methanogenic condition were firstly investigated in this study. The sequences in the bacterial library, grouped into nine OTUs, were all affiliated with $\gamma$-Proteobacteria. The genera Citrobacter and Pseudomonas might have the link with phenanthrene biodegradation under methanogenic conditions. The sequences in the archaeal library could only be grouped into four OTUs, almost all belonging to the phylum Euryarchaeota. The phylum Euryarchaeota comprised only three known genera, Methanosarcina, Methanobacterium and Thermogymnomonas. Genus Methanosarcina might also have links to the phenanthrene degradation process. It seemed that both bacteria and archaea might contribute to phenanthrene degradation. However, the relationship between PAH biodegradation and Methanobacterium (or Thermogymnomonas) remains largely unclear. Further study will be necessary to clarify PAH biodegradation under methanogenic condition.

Acknowledgments This work was supported by the National Natural Science Foundation of China (No. 50979002).

\section{References}

Abdulsalam S, Bugaje IM, Adefila SS, Ibrahim S (2011) Comparison of biostimulation and bioaugmentation for remediation of soil contaminated with spent motor oil. Int J Environ Sci Technol 8(1):187-194

Ammar E, Nasri M, Medhioub K (2005) Isolation of Enterobacteria able to degrade simple aromatic compounds from the wastewater from olive oil extraction. World J Microb Biotechnol 21(3):253259

An SY, Min SK, Cha IH, Choi YL, Cho YS, Kim CH, Lee YC (2002) Decolorization of triphenylmethane and azo dyes by Citrobacter sp. Biotechnol Lett 24(12):1037-1040

Bamforth SM, Singleton L (2005) Bioremediation of polycyclic aromatic hydrocarbons, current knowledge and future directions. J Chem Technol Biotechnol 80(7):723-736

Cébron A, Beguiristai T, Faure P, Norini MP, Masfaraud JF, Leyval C (2009) Influence of vegetation on the in situ bacterial community and polycyclic aromatic hydrocarbon (PAH) degraders in aged PAH-contaminated or thermal-desorption-treated soil. Appl Environ Microbiol 75(19):6322-6330

Chang W, Um YS, Holoman TRP (2005a) Molecular characterization of anaerobic microbial communities from benzene-degrading sediments under methanogenic conditions. Biotechnol Progr 21(6): 1789-1794

Chang W, Um YS, Holoman TRP (2005b) Molecular characterization of polycyclic aromatic hydrocarbon (PAH)-degrading methanogenic communities. Biotechnol Progr 21(3):682-688

Chang W, Um YS, Holoman TRP (2006) Polycyclic aromatic hydrocarbon (PAH) degradation coupled to methanogenesis. Biotechnol Lett 28(6):425-430

Chang YT, Lee JF, Chao HP (2007) Variability of communities and physiological characteristics between free-living bacteria and attached bacteria during the PAH biodegradation in a soil/water system. Eur J Soil Biol 43(5-6):283-296

Chen AC, Imachi H, Sekiguchi Y, Ohashi O, Harada H (2003a) Archaeal community compositions at different depth (up to $30 \mathrm{~m}$ ) of a municipal solid waste landfill in Taiwan as revealed by $16 \mathrm{~S}$ rDNA cloning analyses. Biotechnol Lett 25(9):719-724

Chen AC, Ueda K, Sekiguchi Y, Ohashi A, Harada H (2003b) Molecular detection and direct enumeration of methanogenic 
Archaea and methanotrophic bacteria in domestic solid waste landfill soils. Biotechnol Lett 25(18):1563-1569

Ficker M, Krastel K, Orlicky S, Edwards E (1999) Molecular characterization of a toluene-degrading methanogenic consortium. Appl Environ Microbiol 65(12):5576-5585

Gilles M, Monique A, Jean-Claude B, Philippe C (2010) Response of an archaeal community from anoxic coastal marine sediments to experimental petroleum contamination. Aquat Microb Ecol 59(1): 25-31

Grishchenkov VG, Slepen'kin AV, Boronin AM (2002) Anaerobic degradation of biphenyl by the facultative anaerobic strain Citrobacter freundii BS2211. Appl Biochem Microbiol 38(2):125-128

Gros R, Poly F, Monrozier LJ, Faivre P (2003) Plant and soil microbial community responses to solid waste leachates diffusion on grassland. Plant Soil 255(2):445-455

Großkopf R, Janssen PH, Liesack W (1998) Diversity and structure of the methanogenic community in anoxic rice paddy soil microcosms as examined by cultivation and direct $16 \mathrm{~S}$ rRNA gene sequence retrieval. Appl Environ Microbiol 64(3):960-969

Haritash AK, Kaushik CP (2009) Biodegradation aspects of polycyclic aromatic hydrocarbons (PAHs): a review. J Hazard Mater 169(1-3):1-15

He R, Ruan AD, Jiang CJ, Shen DS (2008) Responses of oxidation rate and microbial communities to methane in simulated landfill cover soil microcosms. Bioresour Technol 99:7192-7199

Huang LN, Zhou H, Chen YQ, Luo S, Lan CY, Qu LH (2002) Diversity and structure of the archaeal community in the leachate of a full-scale recirculating landfill as examined by direct $16 \mathrm{~S}$ rRNA gene sequence retrieval. FEMS Microbiol Lett 214(2): 235-240

Jiries A, Rimawi O, Lintelmann J, Batarseh M (2005) Polycyclic aromatic hydrocarbons $(\mathrm{PAH})$ in top soil, leachate and groundwater from Ruseifa solid waste landfill, Jordan. Int J Environ Pollut 23(2):179-188

Kim M, Bae SS, Seol M, Lee JH, Oh YS (2008) Monitoring nutrient impact on bacterial community composition during bioremediation of anoxic PAH-contaminated sediment. J Microbiol 46(6):615-623

Li CH, Wong YS, Tama NFY (2010) Anaerobic biodegradation of polycyclic aromatic hydrocarbons with amendment of iron (III) in mangrove sediment slurry. Bioresour Technol 101(21):8083-8092

Maidak BL, Cole JR, Lilburn TG, Parker CT, Saxman PR, Farris RJ, Garrity GM, Olsen GJ, Schmidt TM, Tiedje JM (2001) The RDP-II, Ribosomal Database Project. Nucleic Acids Res 29:173-174

Meckenstock RU, Safinowski M, Griebler C (2004) Anaerobic degradation of polycyclic aromatic hydrocarbons. FEMS Microbiol Ecol 49(1):27-36

Mori K, Sparling R, Hatsu M, Takamizawa K (2003) Quantification and diversity of the archaeal community in a landfill site. Can $\mathrm{J}$ Microbiol 49(1):28-36
Narde GK, Kapley A, Purohit HJ (2004) Isolation and characterization of Citrobacter strain HPC255 for broad-range substrate specificity for chlorophenols. Curr Microbiol 48(6):419-423

Ren Y, Peng LH, Deng LJ, Wei CH (2009) Isolation and characterization of Citrobacter farmeri sco1, a novel $m$-cresol-degrading strain. Environ Eng Sci 26(10):1489-1495

Ridgeway HF, Safarik J, Phipps D, Carl P, Clark D (1990) Identification and catabolic activity of well-derived gasoline degrading bacteria and a contaminated aquifer. Appl Environ Microbiol 56(11):3565-3575

Savelieva O, Kotova I, Roelofsen W, Stams AJM, Netrusov A (2004) Utilization of aminoaromatic acids by a methanogenic enrichment culture and by a novel Citrobacter freundii strain. Arch Microbiol 181(2):163-170

Singh C, Lin J (2008) Isolation and characterization of diesel oil degrading indigenous microrganisms in Kwazulu-Natal, South Africa. Afr J Biotechnol 7(12):1927-1932

Sponza DT, Cigal C (2008) Relationships between anaerobic consortia and removal efficiencies in an UASB reactor degrading 2,4 dichlorophenol (DCP). J Environ Manag 87(1):177-192

Tamura K, Dudley J, Nei M, Kumar S (2007) MEGA4, molecular evolutionary genetics analysis, MEGA software version 4.0. Mol Biol Evol 24:1596-1599

Tian YJ, Yang H, Wu XJ, Li DT (2005) Molecular analysis of microbial community in a groundwater sample polluted by landfill leachate and seawater. J Zhejiang Univ Sci B 6(3):165170

Wang Q, Garrity GM, Tiedje JM, Cole JR (2007) Naive Bayesian classifier for rapid assignment of rRNA sequences into the new bacterial taxonomy. Appl Environ Microbiol 73(16):5261-5267

Wang H, Su JQ, Zheng XW, Tian Y, Xiong XJ, Zheng TL (2009) Bacterial decolorization and degradation of the reactive dye Reactive Red 180 by Citrobacter sp CK3. Int Biodeterior Biodegrad 63(4):395-399

Yang Y, McCarty PL (1998) Competition for hydrogen within a chlorinated solvent dehalogenating anaerobic mixed culture. Environ Sci Technol 32(22):3591-3597

Yousefi Kebria D, Khodadadi A, Ganjidoust H, Badkoubi A, Amoozegar MA (2009) Isolation and characterization of a novel native Bacillus strain capable of degrading diesel fuel. Int $\mathbf{J}$ Environ Sci Technol 6(3):435-442

Yu R, Gan P, MacKay AA, Zhang SL, Barth F, Smets BF (2010) Presence, distribution, and diversity of iron-oxidizing bacteria at a landfill leachate-impacted groundwater surface water interface. FEMS Microbiol Ecol 71(2):260-271

Yuan SY, Chang JS, Yen JH, Chang BV (2001) Biodegradation of phenanthrene in river sediment. Chemosphere 43(3):273-278

Zhang SY, Wang QF, Xie SG (2011) Microbial community changes in contaminated soils in response to phenanthrene amendment. Int J Environ Sci Technol 8(2):321-330 